\title{
EURÓPAI ÉS EURÓPÁN TÚLI HORIZONTOK - EZÚTTAL A MENTORKÉPZÉSRŐL
}

\author{
TRENCSÉNYI LÁSZLÓ \\ az Eötvös Loránd Tudományegyetem Pedagógiai és Pszichológiai Karának \\ egyetemi docense \\ trencsenyi.laszlo@ppk.elte.hu
}

Lassan hozzá kell szoknunk, hogy nem cellulóz és festék illatú köteteket lapozgatunk, hanem kékes fényü képernyőnkről olvassuk az információkat. A fiatalabb nemzedék bizonyára már ebben a közegben otthonos, képviselőinek - így leendő és pályakezdő növendékeinknek ez az olvasásmód a természetes, vélhetően megtalálják azokat az ,illatokat” és a mi jó öreg, lapozásainknak megfelelő kellemes szertartásokat ebben az olvasási „üzemmódban”. Így van ez rendjén. Akkor is, ha az iskolák közelében élő nemzedékek különbözősége sosem volt ekkora mint most. E kapcsolatoknak is, meg amazoknak is megvan a maga kultúrája.

Megelőlegezzük már itt, e szándékosan kissé szubjektívre „vett” recenzió elején Győri János kollégánk tanulmányából a már-már kulturális antropológiai leírást. A ,jelenet” ezúttal nem a kopó-újraépülő erzsébetvárosi Kazinczy utcából való, hanem kicsit messzebbről, a szerzőnek oly kedves, megannyi fontos tudósításából ismert Távol-Keletről, Japánból: „Minden olyan iskolában, amelyben legalább egy kezdő tanár kezdi meg a munkáját, az igazgatónak ki kell neveznie egy - szükség esetén természetesen több - mentortanárt. A mentortanároknak a tapasztalt tanárok köréböl kell kikerülniük, ami mögött az az elgondolás húzódik meg, hogy a tapasztalati tudás (tacit knowledge) átadásának a kulcsa az, hogy a mentoráló tanár valóban széles tapasztalatokkal rendelkező, szilárd gyakorlati tudású személy legyen. Ez konkrétan azt jelenti, hogy mentortanárrá általában legalább 20 éves tanítási tapasztalattal rendelkező, gyakran már éppen a nyugdíjas éveik előtt álló tanárok lesznek, illetve egyáltalán nem ritkán a nyugdíjukból külön erre a munkára visszahívott pedagógusok. Ennek következtében a pedagógusi mentorálás japán modelljében tipikusan valóban még egészen fiatal pedagógusújoncok kerülnek össze pályájuk végén járó, idős szakemberekkel. Mindamellett e jellegzetesség értelmezésekor - amelynek során tipikus nyugati megfontolások alapján olyan következtetésekre juthatnánk, mint például az, hogy a mentor és mentorált közötti feltủnően nagy életkori távolság a kommunikációt, egymás megértését nehezítő tényező is lehet természetesen figyelembe veendő az a tény, hogy Japán az úgynevezett gerontokrácia típusú társadalmak mintapéldája, vagyis hogy ebben a társadalomban a munkahelyi előrejutásnak, a társadalmi presztízs elnyerésének egyébként is valóban 
döntő tényezője az életkor. Ami esetünkben azt jelenti, hogy bár a mentor és a mentorált tanár munkajogi viszonyaikat tekintve paritásos viszonyban állnak egymással - ami alapvető különbség a tanárjelölt és vezetőtanára közötti munkaviszonyhoz képest -, valójában automatikusan alá-fölérendeltségi viszony mentén szerveződik meg a munkakapcsolat..."

Azt is mondhatnánk, jól megszerkesztett, egybefonódó életpálya-modellek, nem? De ne vágjunk a dolgok elébe!

\section{I. kötet}

Ennek a - tehát nem papírra nyomott, lapozható, hanem CD-re ,írt”, s számítógépen át, képernyőről olvasható, „lapozható” - „kötetnek” (a sorozat első kötetéről van szó) az írásai a TÁMOP - „Pedagógusképzést segítő szolgáltató és kutatóhálózatok kialakítása pályázatnak A mentorfelkészítés rendszere, próbája, a mentorképzés szakterületi előkészítése alprogramjának keretében jöttek létre. Szerkesztője a hazai pedagógusképzés permanens reformjainak - tán jobban örülne ha így mondanám: folyamatos modernizációjának - hüséges elkötelezettje, egyébként a könyvlapozgatók nemzedékének jeles képviselöje, $M$. Nádasi Mária professzorasszony. Megannyi pedagógusnemzedék, sőt pedagógusképző-nemzedék valóságos mentora. Ez a kettős hivatás: a kutatói-fejlesztői rálátás igénye, $\mathrm{s}$ a pedagógus-mentalitás kettőssége eredeménye e „kötet”. A szerzői körben találunk az ELTE pedagógusképző mühelyeiben gyakorló, tapasztalt egyetemi oktatót (H. Nagy Anna, Bodonyi Edit, a hivatkozott Győri János képviseli e nemzedéket, ill. szerepkört), az erdélyi magyar felsőoktatás reprezentánsát (aki tanítványa volt a föszerkesztőnek Doktori Iskolánkban), Birta-Székely Noémit, a 375 esztendős egyetem társkarának kiválóan felkészült tanárát, Major Évát, a hírneves gyakorlógimnáziumok jeles vezetőtanárait, Szénásiné Steiner Ritát és Tivolt Tímeát, végül a legfiatalabbakat - az immár „Y-generáció” tehetséges szakembereit, akik ösztöndíjasként, segítőtársként, egyetemi hallgatói létüket alig elcserélve a felelős feladatvállalásra, Vámos Gabriellát, Czetö Krisztinát és Kempf Katalint.

Mire vállalkozott ez a - csak látszatra heterogén - kis csapat a professzoraszszony irányításával? A „folyamatos modernizációs” elkötelezettség jegyében hozzájárulni a hazai pedagógusképzésben - szórványos, bár ígéretes, $\mathrm{s}$ feldolgozni érdemes előzmények után - vélhetően dinamikusan kialakuló új szerepkör felkészüléséhez ${ }^{1}$. Mintha a szerkesztő és a szerzők ,ars pedagogica”-ja egybecsengene a Pedagógusképzés legutóbbi számában közreadott közleménnyel, melyben munkahelyüknek,

\footnotetext{
${ }^{1}$ A szórványos előzmények közül nem csupán néhány alternatív iskolánk „betanító-betanuló” párjának példáit idézném, s Gombocz Orsolyára hivatkozva az egyházi iskolák hasonló törekvéseit, de emlékeztetnék arra, hogy a hajdanvolt Pest megyei Pedagógiai Intézetben a 80-as évek legelején a „képesítés nélküli pedagógusok" - lám, ilyen is volt! - pályára állítása érdekében működtettek ilyen együttmüködő párokat (Miltényi Miklós nevéhez füződött e kísérlet).
} 
az ELTE PPK Neveléstudományi Intézetének körültekintő állásfoglalásában fontos alapelv volt, hogy a hazai folyamatok értékelése megkerülhetetlen európai, nemzetközi tapasztalatok elemzése nélkül. A szóban forgó könyv (CD) ezt a feladatot teljesíti a mentorkérdés ügyében: kiterjedt nemzetközi tájékozódás után tanulságos tájékoztatást. Az értelmezési keretek is egybecsengenek a hivatkozott állásfoglalással, melyben ezt olvastuk: „Az Európai Unióban - túl a Bologna-rendszernek alapvetö elemét jelentö sosem vitatott jelentöségén, ti. az egységesülö európai felsőoktatási tér létrehozásán - az elmúlt 10 esztendőben jelentös eröfeszitéseket tettek az oktatás és képzés korszerüsitése, a tudásalapú társadalom megteremtése érdekében. Ezeknek az eröfeszitéseknek szerves részét képezték a pedagógusképzés korszerüsitése irányába kifejtett lépések. "2

A szerkesztő ennél is merészebbet vállalt: az Újvilágtól (Egyesült Államok, Kanada) Kínáig, Japánig, más távol-keleti országokig húzódik a kitekintés horizontja. S amit legalább ennyire fontosnak tartok, manapság szokatlan kíváncsisággal fordultak a kutatók - egy két éves kutatás eredményei mutatkoznak meg egyébként - Európa nyugati fele, a szokásos pedagógiai zarándokutak célpontjai (Anglia, Hollandia, Finnország, Svédország) mellett a közvetlen szomszédok felé (Szlovákia, Románia), illetve a posztszovjet-posztszocialista világ, az egykori „tábor" más országai, a jóformán hasonló helyzetből (az uniformizáltságból) különbözőképpen felzárkózó Csehország és Észtország felé. Az egyes országok oktatási rendszeréhez, pedagógusképzéséhez, különösképp a fiatal pedagógusok, pedagógusjelöltek „szakmai bevezetéséhez” a kutatási időszak alatt különböző eszközrendszerrel lehetett hozzáférkőzni (elsődleges források, szekunder források, interjúk, dokumentumok alapján). S nyilván a különböző eszközrendszerekre, forrástípusokra voltak fogékonyak a különböző kutatói helyzetü, s különböző életkorú kutatók maguk is. Nádasi Mária mintaadó mentori munkáját dicséri, hogy elhivatott pedagógusként fogadta el, s vélelmezem: bátorította a „mentoráltak” egyéni nézőpontjait, kutatási filozófiáját, miközben felnőttnek kijáró felelősséghez jutottak a legfiatalabbak is - hiszen ez a kutatói felelősség neveli, mint tudjuk, a legjobb kutatót.

E recenzió nem tekinti ezúttal feladatának, hogy összefoglaló komparatisztikai tanulmány fogalmazódjék sorai közt. A megoldások szembeszökően különbözőek. Nem egyszerüen eltérö kulturális tradíciókról van szó, olykor alighanem élesen különbözik a problémaérzékenység is egy-egy országban. Bízzuk az olvasóra, hogy ebben a szélesre nyitott legyezőben megtalálja a magyarországi megoldás helyét. Erdemes végigolvasni az esettanulmányokat. Gazdag és korrekt információkat találhatunk.

Az értelmezési keretként a nemzetközi dimenzióban jól ismert és sokat forgatott OECD-munka, az ún. McKensey-jelentés áll (2005-ből), Vámos Gabriella bemutatásában. Előszavában a szerkesztő is a változások szükségének felismerését

\footnotetext{
${ }^{2}$ AZ ELTE Pedagógiai és Pszichológiai Kar Neveléstudományi Intézetének Állásfoglalása a tanárképzés néhány kritikus - és kritika alá vett - kérdéséről. Pedagógusképzés, 2010/1. 117. o.
} 
hangsúlyozza: „minden itt szereplő országban és régióban az iskolarendszer és pedagógusképzés a reformok valamilyen stádiumát éli, tervezi, kezdi, valamely stádiumán túl a tapasztalatokat összegzi, továbblép egy megkezdett úton, kisebb-nagyobb mértékben korrigálva az előzetes terveket. A változtatás szükségességét nem csupán és talán nem is elsősorban a szaktudományok fejlödése, az ismeretek bővülése indokolja, hanem az, hogy a tanítás folyamata nem felel meg a mai gyermekek tanulási igényeinek, az iskolákkal szembeni társadalmi elvárásoknak... Természetesen ez azt is jelenti, hogy alapvetően megváltozik a pedagógus és gyermek viszonya, a pedagógus szerepe az iskolában. Márpedig, ha hatékony, eredményes iskola a társadalmi elvárás, akkor a megváltozott igénynek és szerepnek megfelelö pedagógusfelkészítést kell biztosítani”. Egybecseng ez a szakmai hitvallás a hivatkozott egyetemi állásfoglalással: „,a pedagógusképzés átalakulása sok megoldandó problémát hordoz még magában, ugyanakkor már konkrét előrelépések, eredmények is jelen vannak a megújuló tanárképzésben. A Bologna-i rendszerü tanárképzésbe máris olyan léptékủ emberi erőforrás vonódott be, melynek elherdálása mértéktelen pazarlást jelent."

Bárhogyan is alakul, rajtunk, olvasókon is múlik, hogy például az erre a CD-re másolt tudás se málljon szét a nagy (újra)változások sodrában. Az értelmiségi magatartás mintája legyen tartós: a változások menedzselésének lényegi, megkerülhetetlen eleme a kutatói tájékozódás. Erről szólt Intézetünk sok tanárának közös szövegezésủ nyílt levele is, melyet a még a 2010 tavaszi vizsgaidőszakban ez ETR-en (interneten) keresztül juttattunk el tanárjelöltjeinkhez: „,Kedves hallgatóink! Pedagógusjelöltek, Tanárjelöltek! Vizsgákra készülvén s az oktatási kormányzat intézkedéseiröl szóló hireket is hallgatva bizonyára többükben felmerül a kérdés: mit kezdjenek azokkal a tanulmányaikkal, tanitásokkal: melyeket az ELTE Pedagógiai Pszichológiai Kar kurzusain tanultak fejlesztö értékelésről, a buktatás pszichológiai és társadalmi kockázatairól, a szöveges értékelés fontosságáról, a kompetenciák fejlesztéséröl, az alaptanterv funkcióiról, a társadalmi integrációt szolgáló iskolai integrációs eljárásokról. Megnyugtatjuk Önöket. Legjobb tudásunk szerint, a neveléssel összefüggő tudományok nemzetközi eredményeit követve állitottuk össze tanitási programjainkat, bízzanak bennünk: mindaz, amit tölünk tanulhattak e kérdésekröl: a tudományosság normái szerint vállalható tudások. Úgy gondoljuk, képzésük során nem csupán azt az "üzenetet" próbáltuk meg közvetíteni, hogy pedagógiai nézeteiket mindig a tudományosság mércéjét követve alakitsák ki, de mindig lehetőséget adtunk a kételkedésre, a szabad gondolkodásra is - tudván, hogy növendékeik elé, növendékeik közé, kollégáik mellé állva maguknak kell helytállniuk legjobb lelkiismeretük szerint érvényes pedagógiai célok érvényesitéséért. Szakmai hitelességünkre ezután is számithatnak, tanácsadói-segitő szerepünk nem szünik meg vizsgáik után. Gondolkodjunk együtt, továbbra is közösen a nevelés, oktatás - ha úgy tetszik: az oktatáspolitika - legfontosabb kérdéseiröl.

A Kazinczy utca kapui nyitva állnak..." 


\section{II. kötet}

A minőségbiztosítás aranyszabálya, a PDCA-ciklus tételezése képezi alapját a sorozat második kötetének. A körültekintő tervezés, a kipróbálás szakasza után megjelenik a kontroll igénye, $\mathrm{s}$ a gondos fejlesztők ilyenkor elvégzik az első korrekciókat is. Ezt a szembenézést a háttértanulmányok alapján a szerkesztő, M. Nádasi Mária végzi el. A korrigált koncepciónak lényege az elvi hüség az ún. „ELTE-modellhez”, ám nyitottság a gyakorlati tapasztalatokra figyelő folyamatos alkalmazkodásra. Ebben a stabil, mégis permanens módon önreflektív koncipiálásban hüséges munkatársak s gazdag módszertani eszköztár segít.

Dömsödy Andrea - lévén a könyvtári informatika szakembere - a szakirodalmi áttekintést vállalta elsősorban a mentor-kérdés hazai szerzőit vette számba. 2005 a legkorábbi kiadási évszám, s 33 opuszt talált. Látható: a szakma érdeklődése megindult, kiterjedőben a mentorálás és mentorképzés hazai szakirodalma. Czetö Krisztina a mentorképzési programokat vette szemügyre. Öt intézményben zajlik mentorképzés. Szegeden, Piliscsabán, Egerben, Nyíregyházán és a fővárosi ELTE-n. Hasonlóságok és különbségek, egy fiatal értelmiségi pálya keresi önmeghatározását, képzőik a hozzá vezető utakat, képzési tartalmak árnyalatait. Az is megállapítható, hogy a szegedi és az egri mühely rendelkezik a legkifejtettebb, legszofisztikáltabb programmal. Az elemző összehasonlításaiban még óvatos, a különbségek nem paradigmatikusak, mindenesetre így láttatja. A közvetlenebb empíria szolgál az értékelések kiindulásául a következő szerzőknél (kutatók, mesterek - részt kér az elemzésből maga a szerkesztő is - és frissen végző szakdolgozó, Sági Mónika). Interjúk, kérdőívek alapján gyülnek a tapasztalatok. Antalné Szabó Ágnes és Major Éva vizsgálatainak 245 mentor (39 szak képviseletében), illetve 30 szakot képviselő 59 egyetemi szaktárgy-pedagógus volt adatszolgáltatója. Valamennyien az ELTE Bölcsészkarán megmutatkozó személyek. A természettudósok, illetve informatikusok (Schróth Ágnes - aki az ELTE vonatkozó szakbizottságának is elnöke, s Zsakó László) ezúttal a javaslatok nyelvén juttatták kifejezésre tapasztalataik nyomán keletkezett gondolataikat. Hozzájuk csatlakozik Fótiné Hoffmann Éva a gyógypedagógus tanárképzésben foglalkoztatott mentorokkal összefüggésben.

Mentor? Valamennyi adatgyüjtő és tapasztalatszerző arról tanúskodik, hogy ezúttal a pedagóguspálya univerzumában egy új szakma, új szakmacsoport születik, növekedik megannyi reménnyel, a helykeresés megannyi szakmai kérdésével, akár emberi drámájával. A közoktatás és a felsőoktatás hídjára állított személyek, szakmai csoportok új szellemü, új képzettségü serege készül a pályára - a fiatal szakma öntudatával és félelmeivel, a pedagógusképzés alapkérdéseit újra- és újratárgyaló politikai hullámverések felett. Vajon mi a különbség a gyakorlóiskolai vezetötanár és a mentor között? A gyakorlóiskola és a „világ sürüjében”, olykor peremén elhelyezkedő gyakorlóhely közti évszázados vita is felsejlik a gondolkodók, gyakorlók, irányítók vélekedéseiben. Jelzem: egy új értelmiségi szakma felnöveke- 
dése akkor is teremtene drámai helyzeteket, vélt vagy valós konfliktusokat, ha a környezet egyértelmủen támogató lenne. De hát tudjuk: nem az. A próbatétel sokszoros. S kutató legyen a talpán, aki a diszfunkciókból a független változók befolyását el tudja különíteni a belső, úgymond „saját forrású” ellentmondásoktól, feszültségektől.

Mint írtam: a II. kötet a „minőségbiztosítás” kötete. S a minőségbiztosítás irodalmából jól tudjuk: a külső körülményeket kezeld független változóként, a minőség akkor „terem”, ha az akármilyen, változó környezetre belül érvényes válasz születik. Ez a nyitottság és bizalom jellemzi a második kötetet.

\section{III. kötet}

A III. „kötetben” a mentorképzés gyakorlatához praktikus, egyben „nehézfegyverzetü" elméleti olvasmányok között tallózhatunk. (A DVD formátum lehetővé teszi az újtípusú olvasást, több mint 414 oldalas keménykötésủ kiadványt kevesen vennének kezükbe. E formátum alapján valóban szemezhetnek a különösen gazdag mintákból. Érezhetően a szerzők is élvezettel használták ki a csaknem korlátlan terjedelem kínálta lehetőségeket - óralátogatási - hospitálási napló mintából csaknem tucatnyit találunk. Lehet válogatni! Az alternatívák közti választás lehetősége „filozófiája" a kötet szerkesztőinek.

Valójában az ELTE - különösen mai Pedagógiai és Pszichológiai Kar - „törzsgárdájának” ,jutalomjátéka” az antológia, a „magyar Bolognára” nagy hatást kifejtő ún. „ELTE-tanárképzési modell” egykori kidolgozói, mára hüséges hitvallói foglalják össze tapasztalataikat. Szüret, betakarítás ez, nem csupán számvetés. Nádasi Mária bevezető tanulmánya is ezt a kettős attitüdöt tükrözi. Igényes, korrekt érvelés, hatáselemzés is, egyben bizonyságétel, ha így értelmezné, alkalmazná a felsőoktatás a modellt, akkor a hozzá füzött reményeket igazolná, a kételkedőkből konstruktív kritikust formálna. A következő tanulmányok (úgyszintén az „aranycsapat” szakembereinek, kiemelten Szivák Judit, Lénárd Sándor, Rapos Nóra, Petriné Feyér Judit, Hegedüs Judit, Golnhofer Erzsébet tollából) kulcsszavai tükrözik az ELTE modern-posztmodern ,ars pedagogica”-ját: reflexió, reflexivitás mint a pedagógiai aktivitásokat kísérő, megelőző szellemi tevékenység, támogatás mint a pedagógiai „,beavatkozások” meghatározó gyüjtőfogalma, az elözetes tapasztalatok mint a tudás konstrukciójának tudomásul veendő elöfeltétele, a kompetencia mint a fejlesztendő személyiségjegyek átfogó fogalma. Az iskolaképben pedig meghatározó a rendszerszemléletű, szervezeti gondolkodás. Az már különös karaktere az „ELTE-koncepciónak”, hogy az iskola szakfeladatai, funkciói közül a gyermekvédelem emelkedik ki. Ezt magyarázza a karakterisztikus gyermekjogi szemlélet egyfelől, másfelől a mai iskolai valóság legdrámaibb kihívása iránti fokozott érzékenység képviselete. Mindezt követik a „diszciplináris” tudnivalók. A szerzők az ELTE szakmódszertani mühelyének jelesei. Érdekes az arány: a természettudós- 
ok bizonyultak aktívabbnak és rendszerszerübbnek, a bölcsészetet ezúttal egy-két igényes szemléltető példa képviseli. A természettudományos tantárgypedagógiák képviselői szemmel láthatóan törekedtek arra, hogy kövessék a „pedagógiások” korszerü szemléletmódját, így például az irodalomban is refrénszerüen jelenik meg a projekt, az IKT használata. Hü tükre ez a tantárgypedagógiai seregszemle annak is, miként áll különböző szaktudomány az iskola korszerüsítésének áramlataiban. Ennek elemzése meghaladja e recenzió kereteit.

Birta-Székely Noémi, Bodonyi Edit, Czető Krisztina, Gordon Győri János, H. Nagy Anna, Major Éva, Szénásiné Steiner Rita, Tivolt Tímea, Vámos Gabriella: A mentorfelkészítés rendszere, próbája, a mentorképzés szakterületi előkészítése. I. kötet: A mentorképzés nemzetközi áttekintése. Szerkesztette: M. Nádasi Mária. ELTE Eötvös Kiadó. Budapest, 2010, 223 oldal.

Antalné Szabó Ágnes, Czető Krisztina, Dömsödy Andrea, Fótiné Hoffmann Éva, Jáki Gábor, Major Éva, M. Nádasi Mária, Sági Mónika, Schróth Ágnes, Zsakó László: A mentorfelkészítés rendszere, próbája, a mentorképzés szakterületi előkészítése. II. kötet: A mentorképzés koncepciójáról. Szerkesztette: M. Nádasi Mária. ELTE Eötvös Kiadó, Budapest 2010, 229 oldal.

Feldné Knapp Ilona, Golnhofer Erzsébet, Hegedűs Judit, Horváth Gergely, Illy Judit, Karácsony Éva, Karkus Zsolt, Kempf Katalin, Kriska György, Lénárd Sándor, Makádi Mariann, M. Nádasi Mária, Molnár Gábor Tamás, Petriné Feyér Judit, Rapos Nóra, Révész Judit, Rózsahegyi Márta, Schróth Ágnes, Szalay Luca, Szivák Judit, Vancsó Ödön, Wajand Judit, Wintsche Gergely, Zsakó Lászlóné Bicsak Csilla: A mentorfelkészítés rendszere, próbája, a mentorképzés szakterületi előkészítése. III. kötet. A mentorképzés tartalmáról. Szerkesztette: M. Nádasi Mária. ELTE Eötvös Kiadó, Budapest, 2011, 414 oldal. 